\title{
Obituaries
}

\section{GORDON FELIX HOLMES}

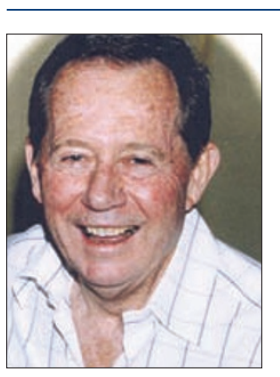

Amongst our profession are those whose enthusiasm for patient care, continuing learning and living a full life is total. Climbing the greasy pole for management positions or engaging in dental politics is both anathema and a distraction. The main characteristic of such colleagues is their modesty. It seems that it is only at the end of their lives that their real worth to their family, our profession and the community is realised. Such a person was Gordon Holmes BDSc DPD FRACDS DOrthRSC DDPHRSC MGDSRCSEng who died on 30 October 2009. Over 300 attended to say goodbye to Gordon in Chelmsford Cathedral. The overwhelming majority had been his patients.

Born in Cairns, North Queensland in 1938 of humble pioneer stock he was evacuated when the Japanese threatened in 1942. After growing up with his mother living on a widow's pension he won a full scholarship to study dentistry at Brisbane University. Gordon came to England in 1965 and built up a large practice in Chelmsford where he employed and mentored scores of associates and trainees. Gordon never stopped learning. In addition to his BDSc he became a Fellow of the Royal Australian College and gained a DDPH St Andrews and both a DOrth and MGDS of the English Royal College. For the last Gordon was in the very first group of candidates who took the examination in 1979. This led to Gordon becoming one of the BSGDS's most active and popular members.
Gordon met Rebecca in 1960 and they had three children. Their daughter Catherine followed her father into Chelmsford practice and Peter moved back to Australia. Michael, his eldest son, said of him 'Many people say they have full lives - but our father really did. He flew fast jets, worked outback trains, lived on two continents and visited all seven. He skied, scuba-dived, bungee jumped at 60 and took surfing lessons at 65. He loved dentistry, and his patients, and continued to practise until the week before his death. We have received hundreds of touching messages from the associates with whom he worked, the nurses he employed, the patients he treated, the myriad of firm friends he made around the world'.

\section{NOEL DAVIES}

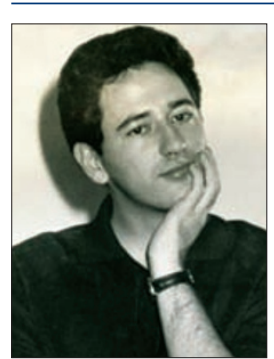

Noel Davies was a larger than life character, who lost his short battle against a particularly aggressive tumour in November 2009.

Noel was a consummate Aus-

tralian whose accent became stronger and prouder in direct relationship to his native country's sporting prowess. Born in 1946 he attended school in Wollongong, New South Wales. He subsequently attended and graduated BDS in 1969 from the University of Sydney, having completed his clinical training at the United Dental Hospital in Sydney.

An Australian who said that he was forced to leave his homeland to avoid sport, he'd decided that Australians
Obituaries should be submitted by email to Kate Maynard at k.maynard@nature.com.

All submitted obituaries should be 350 words maximum in length (apart from obituaries for past presidents of the BDA where the length should be 700-800 words). Content of the obituary is down to the individual author, and the approval of the family should be given for the obituary prior to submission to the $B D J$.

were way too competitive for his taste. This was an excellent example of Noel's dry sense of humour as he became one of the most competitive, ardent and enthusiastic of bridge players to the extent of engaging in online bridge tournaments at $3 \mathrm{am}$ whilst on holiday in Singapore.

Noel was predeceased by his first wife Janine who died in 1992 following longterm renal problems. Noel and April were married in 1995. He is survived by April and by his daughter Karen, also a GDP in the Southampton area, his son Mark, who works in IT, and step-daughters Eugenie and Camille.

Noel built up two excellent dental practices in the Fair Oak and Swaythling districts of Southampton. He was an active member for many years of the British Dental Association, being the Chairman of the Southampton section as well as a leading light and providing a venue for various BDA committee meetings. He also chaired Southampton Local Dental Committee where he was usually either at or the epicentre of any insurrection, especially when it involved faceless bureaucracy, but willingly helping other dentists when he could.

Noel's standards were very high and he always strived to provide the best treatment for his patients. People sought out Noel's company; his wonderfully laid back personality, good humour and wide knowledge on many subjects made it a pleasure to be in his company. He was a wonderful host with great bonhomie. This perfect gentleman will be sorely missed by all his family, friends, colleagues and patients.

Glen Buxey-Softley, Barrie Evans 